\title{
Gene dosage in mammals: characterization of haploid embryonic stem cells
}

\author{
Anton Wutz ${ }^{*}$, Martin Leeb \\ From Epigenetics and Chromatin: Interactions and processes \\ Boston, MA, USA. 11-13 March 2013
}

Most animals are diploid but in several cases haploid genomes can support development to some extent. In contrast to fish, haploidy is not compatible with embryonic development in mammals. Albeit, haploid cells have been observed in egg cylinder stage mouse embryos the majority of surviving embryos becomes diploid. Differences between the development of mammals and fish include genomic imprinting and dosage compensation. Both processes are thought to contribute to the loss of haploid embryos.

Haploid embryonic stem cells (ESCs) have recently been derived from mouse parthenogenetic embryos. These cells maintain key properties of mouse ESCs and might overcome existing limitations in developmental genetic approaches in mice. Haploid ESCs have been established through the activation of unfertilized oocytes from a variety of mouse strains and maintain a wide developmental potential in culture and in chimeric mice. Notably, parthenogenetic haploid ESCs possess robust germline competence enabling the production of transgenic mouse strains from genetically modified haploid ESCs. Contribution to the embryo correlates with an efficient gain of a diploid karyotype. We have also observed that differentiation in culture results in diploidization, which likely is the result of endoreduplication and not cell fusion. In contrast to differentiation into embryonic cell types a haploid karyotype is maintained under certain conditions during forced differentiation to extraembryonic cell fates.

Exploring the differentiation potential of a haploid karyotype highlights developmental constraints imposed by evolutionary adaptations specific for the mammalian genome namely genomic imprinting and $\mathrm{X}$ chromosome inactivation. Our data would suggest that early embryos

Wellcome Trust - Medical Research Council Stem Cell Institute, Department of Biochemistry, University of Cambridge, Tennis Court Road, Cambridge CB2 $1 \mathrm{QR}$, UK

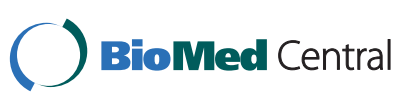

(c) 2013 Wutz and Leeb; licensee BioMed Central Ltd. This is an Open Access article distributed under the terms of the Creative Commons Attribution License (http://creativecommons.org/licenses/by/2.0), which permits unrestricted use, distribution, and reproduction in any medium, provided the original work is properly cited. possess a remarkable ability to buffer disturbances of both epigenetic processes.

Published: 18 March 2013

doi:10.1186/1756-8935-6-S1-O24

Cite this article as: Wutz and Leeb: Gene dosage in mammals: characterization of haploid embryonic stem cells. Epigenetics \& Chromatin 2013 6(Suppl 1):O24.

Submit your next manuscript to BioMed Central and take full advantage of:

- Convenient online submission

- Thorough peer review

- No space constraints or color figure charges

- Immediate publication on acceptance

- Inclusion in PubMed, CAS, Scopus and Google Scholar

- Research which is freely available for redistribution 